\title{
A Case of Unusual Anatomy: Maxillary Central Incisor with Two Root Canals
}

\author{
Un Caso de Anatomía Inusual: Incisivo Central Superior con Dos Canales Radiculares
}

"Evaldo Almeida Rodrigues \& ${ }^{* *}$ Sílvio José Albergaria da Silva

RODRIGUES, E. A. \& SILVA, S. J. A. A case of unusual anatomy: maxillary central incisor with two root canals. Int. J. Morphol., 27(3):827-830, 2009.

SUMMARY: Success in root canal treatment is achieved after thorough cleaning and shaping followed by complete obturation of the canal system. Therefore, endodontic therapy requires specific and complete knowledge of the internal and external dental anatomy, and its variations in presentation. Such treatment may be performed in root canal systems that do not comply with the normal anatomical features described in standard textbooks. The internal anatomy of the maxillary central incisor is well known and usually presents one root canal system. This case report describes an endodontic retreatment of a maxillary central incisor with two canal systems.

KEY WORDS: Central incisor; Two canals; Anatomy.

\section{INTRODUCTION}

One of the main objectives of the endodontic treatment is to prevent or treat apical periodontitis by removing bacterial colonies and necrotic material from the root canal system (Cimili \& Kartal 2002). This is carried out by chemomechanical instrumentation, using files, irrigants and intracanal medicaments. The space created following cleaning and shaping is obturated with a biocompatible filling material that is intended to seal the entire root canal system, thus preventing the ingress of microorganisms (Libfeld et al., 1986). However endodontic treatment can fail for many reasons, such as diagnostic errors, persistence of the infection in the root canal system, errors in debridement and shaping of the root canal systems, instrument fractures, poor restorations and extra roots or canals if not detected are a major reason for failure (Slowey, 1974). Thus, a broad knowledge of both the external and internal anatomy of teeth is of great importance for adequate endodontic treatment (Sponchiado et al., 2006).

Maxillary central incisor has one root and one canal in 100\% of cases (Hess 1925 and De Deus 1960 in: De Deus, 1992), but recently a few cases of dual -rooted maxillary central incisor have been reported in literature. (Sponchiado et al.; Lin et al., 2006; Genovese \& Marisco, 2003; Cimilli
\& Kartal). Therefore, it is important that dentists consider the existence of anatomical variations of root canal systems, and that these variations can also be found in the maxillary central incisors.

The aim of the present study is to show a clinical case of endodontic retreatment of a maxillary central incisor with two root canals.

\section{CASE REPORT}

A 25 year-old white female patient was referred by his general dental practitioner for root canal retreatment of the maxillary central incisor. She complained of spontaneous pain and her medical history was unremarkable and noncontributory.

Clinical examination revealed that there was a swelling buccally on the level of the central incisor and there was tenderness to palpation and percussion.

Radiographic examination showed that the tooth had

\footnotetext{
* Graduate student, School of Dentistry of the Federal University of Bahia, Salvador, Bahia, Brazil.
}

${ }^{* *}$ MSc, School of Dentistry of the Federal University of Bahia, Salvador, Bahia, Brazil. 
been previously treated, but remained with a periapical lesion (Fig.1). It also showed only one canal obturated until the end, but beside it, a narrow line of filling material appeared, suggesting that there was another canal (Fig.1).

The tooth was isolated with rubber dam and access was gained to the pulp chamber with high-speed round diamond bur number 1015 (KG Sorensen, Burveri, SP). After that procedure, a compensatory wearing was carried out with a high-speed Endo-Z stainless steel bur (Maillefer-Dentsplay, Switzerland) to improve the exploration of canals. The filling material was removed with the aid of Gates Glidden burs, size 1, 2 and 3 (Maillefer-Dentsplay, Switzerland). The canals were explored (a lingual and a buccal one) and the working length was determined (Fig.2). After that, the chemomechanical preparation was carried out by the crowndown technique with KFlexofile (Maillefer-Dentsplay, Switzerland) under continuous irrigation with $2.5 \%$ sodium hypochlorite solution (Brilux, Brazil).

When preparation was complete, the canals were dried with paper points and a calcium hydroxide dressing was placed (Calen, SS White, Brazil). One week later the cones were tested (Fig.3) and, the root canal system was obturated by lateral condensation of gutta- percha with a calcium hydroxide based sealer (Sealapex-Sybron/Keer, USA). The tooth was restored subsequently and six months later, the tooth was clinically asymptomatic and radiographically without periapical lesion (Fig. 4).

\section{DISCUSSION}

Most endodontic and dental anatomy texts describe the human maxillary central incisors with single root and single canal (Weine, 1989; De Deus; Ingle \& Backland, 1994; Leonardo \& Leal, 1998; Walker, 1998; Roldi et al., 1999). There were few cases reports describing an additional canal in maxillary central incisors (Sponchiado
Fig. 4. Control radiograph. 
et al.; Genovese \& Marsico; Lin et al.). Other cases that have been mentioned were germination or fusion teeth (Libfeld et al.; Cimili \& Kartal).

A correct diagnosis before treatment is fundamental in teeth of this type. Radiographic examination with varying angles should be undertaken, when faced with a suspicious image.

Working in a crown-down manner has many advantages. First, the root canal system is likely to be most heavily infected in coronal area. Carrying out coronal flaring before proceeding into the apical regions of the root canal system will remove the majority of these bacteria early in preparation and also prevent the inoculation of periapical tissues with bacteria that may be carried down the root canal system with hand files. A lateral condensed gutta-percha technique was used to obturate the root canal system, as this was considered to be more predictable by the authors.
From a clinical standpoint, only by correct examination and interpretation of radiographic images can the clinician detect variations in both root and canal anatomy and be aware of them before and during endodontic procedures.

\section{CONCLUSION}

The lack of knowledge about all possible root canal anatomical configurations can lead dentists to leave remaining necrotic tissue and toxic products used during endodontic procedures in the additional nontreated canal, resulting in an unsuccessful endodontic treatment. Thus, this study demonstrated the importance of a correct diagnosis for the endodontics, and that the clinician should be careful that even the most routine of cases might deviate from the usual.

RODRIGUES, E. A. \& SILVA, S. J. A. Un caso de anatomía inusual: incisivo central superior con dos canales radiculares. Int. J. Morphol., 27(3):827-830, 2009.

RESUMEN: El éxito de los tratamientos de endodoncia sólo puede conseguirse mediante una completa asepsia, el modelado y la obturación del canal radicular. Por ello, los tratamientos de endodoncia requieren de un completo y detallado conocimiento de la anatomía interna y externa de los canales radiculares y de sus variantes. Este tipo de tratamiento puede realizarse en canales radiculares que no coincidan con las características anatómicas normales descritas como patrón por la literatura. La anatomía interna de los incisivos centrales superiores es bien conocida, presentando normalmente un canal radicular único. En este relato se describen los tratamientos endodóncicos de incisivo central superior con dos canales radiculares.

\section{PALABRAS CLAVE: Incisivo Central; Dos canales; Anatomía.}

\section{REFERENCES}

Cimili, H. \& Kartal, N. Endodontic Treatment of Unusual central Incisors. J. Endod., 28:480-1, 2002.

De Deus, Q. D. Endodontia. $5^{\text {th }}$ Ed. Rio de Janeiro, Medsi, 1992.

Genovese, F. R. \& Marsico, E. M. Maxillary central incisor with two roots: A case Report. J. Endod., 29:220-1, 2003.

Ingle, J. I. \& Backland, L. K. Endodontics. $4^{\text {th }}$ Ed. Baltimore, Williams \& Wilkins, 1994. pp.92-227.

Leonardo, M. R. \& Leal, J. M. Endodontia. Tratamento dos Canais Radiculares. $3^{\text {th }}$ Ed. São Paulo, Panamericana, 1998. pp.191-214.

Libfeld, H.; Stabholz, A. \& Friedman, S. Endodontic therapy of bilaterally geminated permanent maxillary central incisor. J. Endod., 12:214-6, 1986.
Lin, W. C.; Yang, S. F. \& Pai, S. F. Nonsurgical endodontic treatment of a two-rooted maxillary central incisor. $J$. Endod., 32:478-81, 2006.

Roldi, A.; Pereira, R. S. \& Azeredo, R. A. Anatomia interna, cavidade de acesso e localização dos canais. In: Lopes, H. P. \& Siqueira, J. F. Jr. Endodontia. Biologia e Técnica. $1^{\text {th }}$ Ed. Rio de Janeiro, Medsi, 1999. pp.11937.

Slowey, R. R. Radiographic AIDS in the detection of extra root canals. Oral Surg., 37:762-72, 1974.

Sponchiado, E. C. Jr.; Ismail, H. A.; Braga, M. R.; de Carvalho, F. K. \& Simões, C. A. Maxillary central incisor whit two root canals: A case report. J. Endod., 32:10024, 2006.

Walker, R. T. Pulp space anatomy and access cavities. In: 
Pitt Ford, T. R. Harty's Endodontics in Clinical Practice. $4^{\text {th }}$ Ed. Oxford, UK., Wright, 1998. pp.16-36.

Weine, F. S. Endodontic Therapy. $4^{\text {th }}$ Ed. St. Louis, Mosby, 1989. pp.245-51.
Correspondence to:

Evaldo Almeida Rodrigues

Address- Alto do Paraguai Street, 280. SIM district, Feira de Santana, Bahia

Zip code- 44042310

BRAZIL

Phone: 557532231738

Email: evaldo.dr@gmail.com

Received: 25-02-2009

Accepted: 01-06-2009 